\title{
A retrospective analytic study of clino-histopathological correlation of ovarian mass
}

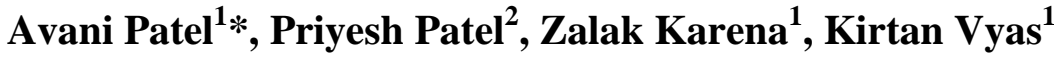

\begin{abstract}
${ }^{1}$ Department of Obstetrics and Gynecology, P. D. U. Medical College, Rajkot, Gujarat, India
${ }^{2}$ Department of Obstetrics and Gynecology, Gujarat Cancer and Research Institute, Asarwa, Ahmadabad, Gujarat, India
\end{abstract}

Received: 09 August 2016

Revised: 17 September 2016

Accepted: 20 September 2016

\author{
*Correspondence: \\ Dr. Avani Patel, \\ E-mail: avanipate19319@gmail.com
}

Copyright: () the author(s), publisher and licensee Medip Academy. This is an open-access article distributed under the terms of the Creative Commons Attribution Non-Commercial License, which permits unrestricted non-commercial use, distribution, and reproduction in any medium, provided the original work is properly cited.

\begin{abstract}
Background: Ovarian tumours account for $30 \%$ of all cancers of female genital tract. The study of histology of ovarian masses therefore is of prime importance. The objective of the study was the clinical and histopathological presentation of ovarian masses.

Methods: This is a retrospective analysis of 44 patients with ovarian masses from January 2014 to December 2014 at P. D. U. Medical College, Rajkot. Patients with ovarian masses who were surgically managed were included in the study. Patients with non-ovarian masses and those who were conservatively managed were excluded. The data was collected in Excel Sheet and analyzed by descriptive statistics and Chi-Square Test.

Results: Incidence of Ovarian masses was $20.85 \%$ in our Institute. Among 44 cases $54.5 \%$ were neoplastic. Among the neoplasms $95.83 \%$ were benign and $4.16 \%$ were malignant. Mean age of presentation of benign neoplasm was 38 years and that of malignant was 50 years. Incidence of non-neoplastic ovarian masses was $45.5 \%$. Mean age of presentation of non-neoplastic ovarian masses was 31 years. Pain in abdomen was the most common clinical presentation of both neoplastic and non-neoplastic ovarian masses. Mucinous Cystadenoma and Teratoma-Dermoid Cyst were the commonest benign tumor followed by Serous Cystadenoma.

Conclusions: In our study, non-neoplastic ovarian masses presented in equal proportions as that of neoplastic ovarian masses. 31-40 years age group showed the highest propensity of occurrence of Ovarian Masses. Mucinous Cystadenoma was highly emerged most common benign Ovarian Mass in this study.
\end{abstract}

Keywords: Ovarian masses, Teratoma, Mucinous cystadenoma

\section{INTRODUCTION}

Ovarian tumours account for $30 \%$ of all cancers of female genital tract. ${ }^{1}$ The total number of ovarian cancer cases worldwide has been estimated to be approximately 2 lakhs/year. It presents for approximately one fifth of the cancer deaths worldwide.

The etiology of ovarian tumours is still an issue of debate. The role of fallopian tube tumour cell spread to Ovary is being hypothesized rather than the ovary per se.
This contradicts to the discussion of role of ovulation induction in development of ovarian cancer. The study of histology of ovarian masses therefore is of prime importance.

\section{METHODS}

This is a retrospective analysis of 44 patients with ovarian masses from January 2014 to December 2014 at P. D. U. Medical College, Rajkot, Gujarat, India. 
Patients with ovarian masses who were surgically managed were included in the study. Patients with nonovarian masses and those who were conservatively managed were excluded. Demographic details like age, menstrual status, obstetric history, presenting symptoms, and surgery details were noted. Histopathological examination of the surgically removed tissue was conducted in the Department of Pathology of the same institute with appropriate stains.

The data was collected in excel sheet and analysed by descriptive statistics and Chi-square test.

\section{RESULTS}

Out of 211 admissions in the Gynecology ward, incidence of ovarian masses was $20.85 \%$ (44 Patients) and that of ovarian neoplasm was $11.37 \%$ (24 Patients). Among ovarian masses, neoplasms accounted for $54.5 \%$ (23/44) and non-neoplasms accounted for $45.5 \%$ (21/44). Mean age of non-neoplastic ovarian mass was 32 years and benign neoplasm was 38 years and malignant was 50 years respectively.

\section{Clinical presentation}

Age distribution

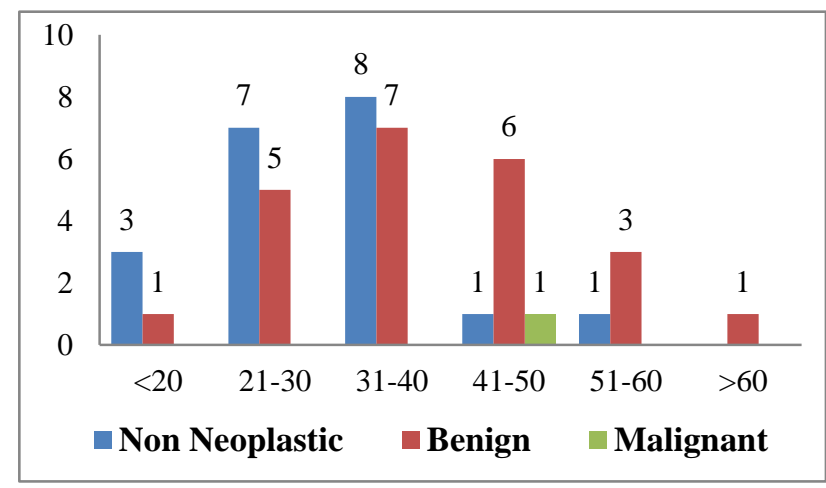

Figure 1: Distribution of ovarian masses in various age groups.

Table 1: Demographic and obstetric profile among ovarian masses.

\begin{tabular}{|llll|}
\hline Parameters & $\begin{array}{l}\text { Non- } \\
\text { neoplastic }\end{array}$ & Benign & Malignant \\
\hline Menstrual status & & & \\
\hline Reproductive & 18 & 15 & \\
\hline Post-menopausal & 2 & 8 & 1 \\
\hline Sterilization & & & \\
\hline Yes & 2 & 6 & \\
\hline No & 18 & 17 & 1 \\
\hline Parity & & & \\
\hline Nulliparous & 5 & 2 & \\
\hline 1,2 & 8 & 7 & 1 \\
\hline$>3$ & 7 & 14 & \\
\hline
\end{tabular}

Maximum numbers of non-neoplastic and benign cases were noted in 31-40 years age group. The only one patient with malignancy in our study group was 50 years old. The distribution of ovarian masses in different age groups is shown in Figure 1.

Table 1 shows menstrual status, sterilization, parity details of study group and its distribution amongst nonneoplastic, benign and malignant ovarian masses.

Most common presenting symptom irrespective of the type of tumour was pain in abdomen. One case with malignancy of ovarian mass presented with abdominal mass, pain in abdomen, weight loss and nausea.

Table 2: Clinical presentation of ovarian masses.

\begin{tabular}{|lll|}
\hline Symptoms & $\begin{array}{l}\text { Non-neoplastic } \\
(\%)\end{array}$ & $\begin{array}{l}\text { Benign } \\
(\%)\end{array}$ \\
\hline Pain abdomen & 90 & 86.95 \\
\hline Mass in abdomen & 15 & 17.39 \\
\hline Abdominal symptoms & 5 & 21.73 \\
\hline Menstrual symptoms & 10 & 21.73 \\
\hline Urinary symptoms & 5 & 21.73 \\
\hline $\begin{array}{l}\text { Constitutional } \\
\text { symptoms }\end{array}$ & 25 & 17.39 \\
\hline Asymptomatic & 5 & Nil \\
\hline
\end{tabular}

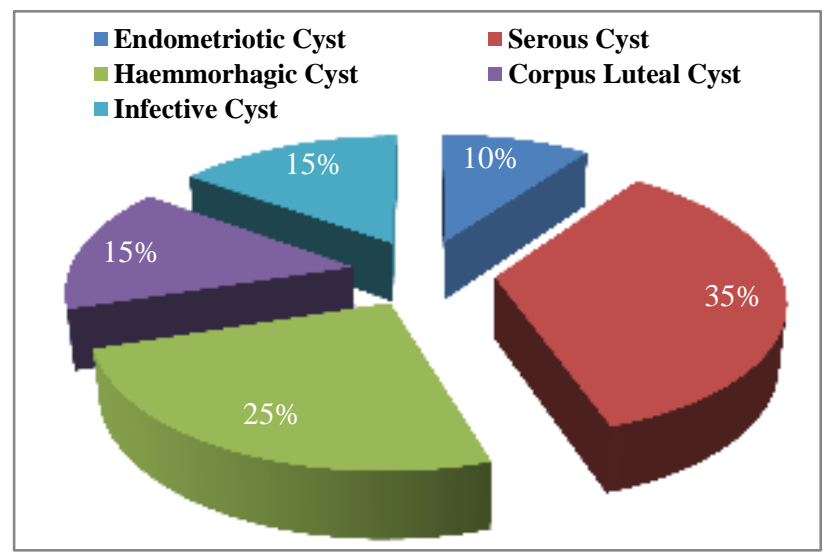

Figure 2: Histopathological pattern of non-neoplastic ovarian tumours.

Among the non-neoplastic masses, the commonest was serous cyst (35\%) followed by Haemorrhagic cyst (25\%). Histological pattern of non-neoplastic tumours is shown in above pie Figure 2.

There were 7 patients of Mucinous Cystadenoma, 7 patients of Cystic Teratoma, 6 patients of Serous Cystadenoma, 2 cases of Thecoma and 1 patient of Papillary Cystadenoma.

There was one patient of malignancy-Serous Papillary Adenocarcinoma, which was referred to higher center for chemotherapy. 


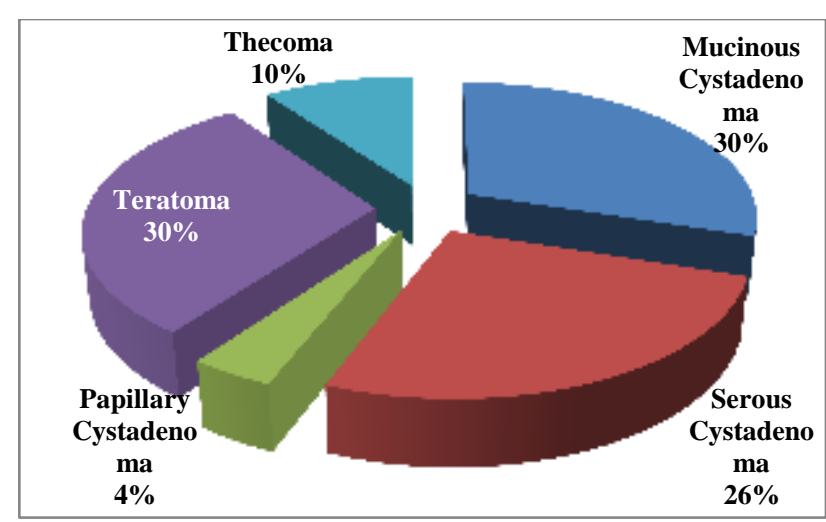

Figure 3: Histopathological pattern of benign ovarian masses.

\section{DISCUSSION}

In the present study, incidence of ovarian masses is $20.85 \%$ in our institute. In our study, maximum number of patients belonged to age group of 31 to 40 years which was similar to Shraddha SO et al study. ${ }^{2}$ However in Makwana $\mathrm{HH}$ et al, the maximum number of patients belonged to 21 to 30 years age group.

In our study, patients without sterilization had 4 times higher incidence of having Ovarian Mass as compared to those who had done sterilization. But, Shraddha SO et al. study does not show any relation between sterilization and ovarian neoplasms.

Relation between Nulliparity and ovarian neoplasm is not statistically significant in our study which is comparable to Shraddha SO et al study.

Table 3: Comparisons between our study and other related studies.

\begin{tabular}{|lllll|}
\hline Parameter & Our study & Shraddha SO et al & Makwana HH et al & Kanthikar SN et al $^{3}$ \\
\hline Period of study & 1 year & 4 years & 11 years & 3 years \\
\hline No. of cases & 44 & 205 & 337 & 145 \\
\hline Place of study & $\begin{array}{l}\text { P. D. U. Medical } \\
\text { College, Rajkot }\end{array}$ & $\begin{array}{l}\text { Medical College, } \\
\text { South India }\end{array}$ & $\begin{array}{l}\text { C. U. Shah Medical } \\
\text { College Rajkot }\end{array}$ & $\begin{array}{l}\text { Tertiary Care Center, } \\
\text { Dhule Maharashtra }\end{array}$ \\
\hline $\begin{array}{l}\text { No. of non- } \\
\text { neoplastic cases }\end{array}$ & 21 & 65 & 197 & 75 \\
\hline $\begin{array}{l}\text { No. of neoplastic } \\
\text { cases }\end{array}$ & 23 & 140 & 140 & 70 \\
\hline
\end{tabular}

Table 4: Comparison of histopathological pattern of ovarian masses.

\begin{tabular}{|lllll|}
\hline Parameter & Our Study & Shraddha SO et al & Makwana HIH et al & Kanthikar SN et al \\
\hline M/C non-neoplastic & Serous cyst & Endometriotic cyst & Serous cyst & Serous cyst \\
\hline M/C benign & Mucinous cystadenoma & Serous cystadenoma & Serous cystadenoma & Serous cystadenoma \\
\hline M/C malignant & $\begin{array}{l}\text { Serous } \\
\text { cystadenocarcinoma }\end{array}$ & $\begin{array}{l}\text { Serous } \\
\text { cystadenocarcinoma }\end{array}$ & $\begin{array}{l}\text { Serous } \\
\text { cystadenocarcinoma }\end{array}$ & $\begin{array}{l}\text { Serous } \\
\text { cystadenocarcinoma }\end{array}$ \\
\hline
\end{tabular}

M/C-most common

\section{CONCLUSION}

In our study, non-neoplastic ovarian masses presented in equal proportions as that of neoplastic ovarian masses. 31-40 years age group showed the highest propensity of occurrence of Ovarian Masses. Mucinous Cystadenoma was highly emerged most common benign Ovarian Mass in our study.

Funding: No funding sources Conflict of interest: None declared

Ethical approval: The study was approved by the Institutional Ethics Committee

\section{REFERENCES}

1. Uma Devi K. Current status of gynecological cancer care in India. J Gynecol Oncol. 2009;20(2):77-80.

2. Shraddha SO, Sridevi TA, Renukadevi TK, Gowri R, Binayak D, Indra V. Ovarian Masses: Changing Clinico Histopathological Trends. J Of Obst Gyne Of India. 2015;65(1):34-8.

3. Makwana HH, Maru AM, Lakum NR, Agnihotri AS, Trivedi NJ, Joshi JR. The relative frequency and histopathological pattern of ovarian masses-11yeaar studyat tertiary care centre. Int J Med Sci Public Health. 2014;3(1):81-4.

4. Kanthikar SN. Clinico-Histopathological Analysis of Neoplastic Lesions of the Ovary: A 3-Year Prospective Study in Dhule, North Maharashtra, India. J Clin Diagn Res. 2014;8(8):FC04-7. 
5. Parkin DM, Bray F, Ferlay J. Global cancer statistics, 2002. CA Cancer J Clin. 2005;55(2):74108.

6. Murthy NS, Shalini S, Suman G. Changing trends in incidence of ovarian cancer- the Indian Scenario. Asian Pac J Cancer Prev. 2009;10(6):1025-30.

7. Yeole BB, Kumar AV, Kurkure A. Population-based survival from cancers of breast, cervix and ovary in women in Mumbai, India. Asian Pac J Cancer Prev. 2004;5(3):308-15.

8. Mondal SK, Banyopadhayay R, Nag DR. Histologic pattern, bilaterality and clinical evaluation of 957 ovarian neoplasms: A 10 year study in a tertiary hospital of eastern India. J Cancer Res Ther. 2011;7(4):433-7.

9. Wasim T, Majrroh A, Siddiq S. Comparison of clinical presentation of benign and malignant ovarian tumors. J Pak Med Assoc. 2009;59:1.

Cite this article as: Patel A, Patel P, Karena Z, Vyas $\mathrm{K}$. A retrospective analytic study of clinohistopathological correlation of ovarian mass. Int J Reprod Contracept Obstet Gynecol 2016;5:3802-5. 